\title{
CYP11A1 Gene
}

National Cancer Institute

\section{Source}

National Cancer Institute. CYP11A1 Gene. NCI Thesaurus. Code C40056.

This gene is involved in steroid metabolism. 